\begin{tabular}{|c|c|c|}
\hline & $\begin{array}{c}\text { Proceeding } \\
\text { International Conference on Islamic Educational Guidance and Counseling } \\
\text { 9 December 2021 } \\
\text { E-ISSN: 2827-9581 } \\
\text { Website: http://conference.iainsalatiga.ac.id/index.php/iciegc }\end{array}$ & $\begin{array}{l}\text { PEBf } \\
\text { HIm. 228-240 }\end{array}$ \\
\hline
\end{tabular}

\title{
PELAKSANAAN PENDIDIKAN KARAKTER DI SMK IT KHOIRU UMMAH REJANG LEBONG
}

\author{
Sri Mulyati ${ }^{1}$, Sri Astuti ${ }^{2}$, Nelsi Zahara ${ }^{3}$, Purba Sentosa $^{4}$, Rahmad Hidayat $^{5}$ \\ 1,2,3,4,5 IAIN Curup
}

\begin{tabular}{|c|c|}
\hline Informasi Artikel & ABSTRACT \\
\hline $\begin{array}{l}\text { Penulis Korespondensi: } \\
\text { Sri Mulyati } \\
\text { Email: msri0444@gmail.com }\end{array}$ & $\begin{array}{l}\text { Discussions on character education have been widely studied in } \\
\text { research, both from literature and empirical studies, but the } \\
\text { presentation of achievement results is varied and varies depending on } \\
\text { the indicators of the character education values discussed. Therefore, } \\
\text { this study aims to describe all the value indicators in character } \\
\text { education, namely } 18 \text { values that have been implemented by SMK IT } \\
\text { Khoiru Ummah Rejang Lebong. Based on the study and analysis of } \\
\text { the contents of the literature used as a reference for this study, it was } \\
\text { concluded that the development of character education is a must } \\
\text { because the world of education not only makes students smart, but } \\
\text { also has character and manners so that their existence as members of } \\
\text { the community becomes meaningful for the community. himself and } \\
\text { others. Furthermore, at SMKIT Khoiru Ummah Rejang Lebong, in } \\
\text { general, character education has been instilled in all students through } \\
\text { various types of superior school programs which are carried out in } \\
\text { accordance with the demands of the values in character education. }\end{array}$ \\
\hline
\end{tabular}

\begin{abstract}
Keyword: Character education
ABSTRAK

Pembahasan tentang Pendidikan Karakter telah banyak dikaji dalam penelitian, baik dari study literatur maupun empirik, namun pemaparan tentang hasil pencapaian menjadi beragam dan bervariasi tergantung dengan indikator dari nilai pendidikan karakter yang di bahas. Oleh karena itu penelitian ini bertujuan untuk memaparkan seluruh indikator nilai yang ada dalam pendidikan karakter yaitu 18 nilai yang telah dilaksanakan oleh SMK IT Khoiru Ummah Rejang Lebong. Berdasarkan telaah dan analisis isi literatur yang digunakan sebagai rujukan study ini diperoleh simpulan bahwa pembangunan pendidikan karakter menjadi suatu keharusan karena dunia pendidikan tidak hanya menjadikan peserta didik menjadi cerdas, akan tetapi juga mempunyai budi pekerti dan sopan santun sehingga keberadaannya sebagai anggota masyarakat menjadi bermakna baik bagi dirinya maupun orang lain. Lebih lanjut di SMKIT Khoiru Ummah Rejang Lebong, secara umum telah menanamkan pendidikan karakter kepada seluruh santrinya melalui berbagai jenis program unggulan sekolah yang dilaksanakan sesuai dengan tuntutan nilai-nilai yang ada dalam pendidikan karakter.
\end{abstract}

Kata kunci: Pendidikan karakter 


\section{PENDAHULUAN}

Bunyi Undang-Undang Repuplik Indonesia No. 20 Pasal 3, pendidikan nasional yaitu untuk mengembangkan serta membentuk watak peradaban bangsa yang bermartabat untuk mewujudkan cita-cita bangasa yaitu mencerdaskan kehidupan berbangsa serta berupaya untuk mengembangkan potensi serta kemampuan pe berserta didik dan menjadikan mereka menjadi manusia yang beriman, berakhlak mulia, berilmu cakap, kreatif, mandiri dan menjadi warga Negara yang demokratis serta bertanggung jawab.(UU Sisdiknas, 2003). Secara ideal tujuan pendidikan nasional kita telah merujuk kepada tiga ranah yaitu kognitif, afektif dan psikomotor. Seluruh pelaku pendidikan harus ikut serta dalam mewujudkan tujuan pendidikan nasional tersebut.

Beranjak dari hal tersebut di atas, pendidikan seharusnya mampu membentuk karakter pada peserta didik, dimana karakter sangat erat hubungannya dengan cara bertingkah laku. Pendidikan karakter harus diberikan sedini mungkin pada tiap jenjang pendidikan baik formal maupun non formal.

Dalam implementasinya di lingkungan sekolah, pendidikan karakter harus dimulai dari guru, guru bukan hanya memberikan pelajaran karakter tetapi guru harus mampu menempa dirinya terlebih dahulu agar berkarakter. Pendidikan karakter mengedepankan contoh bertingkah laku dari pada berilustrasi, materi pendidikan karakter dipahamkan melalui kegiatan pembelajaran dalam metode dan tingkah laku dan bukan diwujudkan melaui tes.

Upaya pendidikan karakter dapat dibentuk jika setiap individu memiliki teladan yang mampu mengiring peserta didik dalam ranah yang jelas, tegas dan benar, maka sebaiknya upaya pendidikan karakter dilakukan kepada peserta didik dari tingkat dasar dan menengah. Para peserta didik disiapkan untuk mampu menyikapi pilihan hidup dengan bijak. Namun, sekolah bukan satu-satunya tempat untuk mendidik setiap pribadi yang berkakakter, tempat lain yang utama adalah lingkungan keluarga dan lingkungan masyarakat. rumah adalah istana bagi penghuninya tetapi rumah bisa jadi penjara bila tampa komunikasi, begitu juga dengan masyarakat yang bisa jadi penyekat apabila tidak ada empati yang dirasakan. Jadi dapat disimpulkan bahwa semua individu adalah pelaku pendidikan karakter bagi peserta didik.

Meskipun pendidikan berkarakter sudah mulai diterapkan di sekolah- sekolah di Kabupaten Rejang Lebong baik disekolah dasar, menengah dan menengah atas, namun realita di lapangan belum sesuai dengan yang harapankan, hal ini terlihat dari masih 
banyaknya peserta didik yang bermasalah khusunya yang terjadi di sekolah menengah atas baik di SMA maupun di SMK, seperti masih adanya siswa yang sering tidak masuk sekolah tampa keterangan (alpa), membolos dari sekolah atau dari kelas saat jam pelajaran tertentu, sering datang terlambat, ketahuan merokok, berbohong, berkelahi atau tauran dan masih banyak lagi permasalahan yang ditemukan di lingkungan sekolah.

Dalam pendidikan Islam dikenal istilah-istilah ta'lim, tarbiyah, dan ta'dib. Ketiga istilah ini bila ditelusuri lebih lanjut, masing-masing sebenarnya mempunyai makna tersendiri dalam hubungannya dengan pendidikan. Namun, istilah yang komprehensif untuk pendidikan Islam ini, seperti yang ditemukan oleh al Attas adalah at ta'dib (pendidikan karakter) (Normoslim dalam Hartini, 2017).

Idi warsah dalam bukunya Pendidik Inspiratif menyebutkan bahwa kompetensi pendidik yang dibutuhkan dizaman sekarang ada enam yaitu: religius, bijaksana dan pemaaf, interkultural, berpikir kritis, berwawasan teknologi dan inovatif, hal tersebut senada dengan konsep pendidikan karakter yang salah satunya adalah muatan religius.

Berdasarkan uraian diatas, maka penulis akan melakukan penelitian bagaimana pelaksanaan pendidikan berkarakter yang diterapkan di SMK IT Khoiru Ummah Rejang Lebong.

\section{METODE}

Dalam penelitian ini, peneliti menggunakan metode deskriftif kualitatif dengan alasan karena penelitian ini hanya bertujuan untuk mendeskripsikan data-data dan informasi yang diperoleh dilapangan (lokasi penelitian) terkait dengan pelaksanaan pendidikan karakter. Setelah itu informasi tersebut direduksi, didisplay serta disajikan sesuai dengan prosedur penelitian. Pendekatannya menggunakan berbagai study literatur. Sastra yang digunakan adalah jurnal dan buku pendukung pengembangan gagasan tentang Pendidikan Karakter. Penulis menyusun kerangka kerja konseptual terkait pendidikan karakter.

Semua data dan informasi yang diperlukan terkait dengan pelaksanaan program pendidikan karakter ini semua di kumpulkan dari pihak SMKIT Khoiru Ummah Rejang Lebong. Informasi-informasi tersebut diperoleh dari kepala sekolah, wakil bagian kurikulum, wakil bagian kesiswaan, Guru BK, dan seluruh dewan guru yang ada di SMKIT Khoiru Ummah.

Teknik pengumpulan data dalam penelitian ini adalah study dokumentasi yaitu meliputi: 1) Data Pribadi yang terkait dengan pelaksanaan program pendidikan karakter di SMKIT Khoiru Ummah diantaranya: buku harian kegiatan sekolah, surat menyurat dan 
catatan lainnya; dan 2) Data Resmi terkait pelaksanaan program pendidikan karakter di SMKIT Khoiru Ummah berupa memo, pengumuman-pengumuman, laporan rapat, dan yang lainnya.

\section{HASIL DAN BAHASAN}

\section{Hasil}

Berikut adalah hasil riset mengenai penerepan pendidikan karakter yang dilakukan di SMK IT Khoiru Ummah Rejang Lebong. Pelaksanaan pendidikan karakter yang telah diterapkan oleh para pendidik di SMK IT Khoiru Ummah Rejang Lebong adalah:

\section{Religius}

Dalam hal religius atau keagamaan ini menjadi program prioritas di SMK IT Khoiru Ummah dalam memberikan pemahaman nilai-nilai keagamaan yang berupa sholat dhuha, pembacaan al-ma'surat, muroj'ah, baca Al-qur'an dengan metode wafa (cara cepat baca alqur'an) yang semua itu dilakukan setiap pagi sebelum pembelajaran dimulai. Kemudian sholat dzuhur berjamaah dilanjutkan dengan dzikir, do'a dan setelah itu dilanjutkan pembacaan hadits secara bersama-sama. Nilai pendidikan karakter yang didapatkan oleh santri berupa pemahaman, pengetahuan serta mengamalkan nilai religius itu untuk kehidupan bermasyarakat nantinya.

2. Jujur

Dalam penerapan kejujuran para santri, para pendidik memberikan tugas yang berupa individu maupun kelompok, setoran hafalan dan mengadakan sebuah kantin kejujuran yang dimana para santri membeli jajanan dikantin tersebut serta membayarnya tanpa sepengetahuan para pendidik serta ditambah lagi pada pembelajaran pendidikan agama islam dan budi pekerti. Nilai pendidikan karakter yang diperoleh oleh santri yaitu menanamkan nilai kejujuran yang dapat dipercaya dalam perkataan, perbuatan serta kepercayaan walaupun orang-orang tidak melihatnya akan tetapi Allah selalu melihat apa yang kita lakukan.

\section{Toleransi}

Dalam sikap toleransi ini sangatlah penting dan harus dimiliki oleh para santri, maka disini guru BK berperan penting dalam memberikan pemahaman terhadap bertoleransi dengan menggunakan beberapa layanan dalam konseling yaitu, layanan informasi dan bimbingan kelompok. Dalam memberikan layanan tersebut guru BK memberikan pemahaman mengenai sikap toleransi antar teman sebaya, guru dan seluruh warga SMK IT 
Khoiru Ummah serta masyarakat luas. Nilai pendidikan karakter yang didaptkan yaitu bagaimana bersikap toleransi antar teman sebaya khususnya, karena perbedaan budaya dan pendapat sangat jelas baik didalam kelas maupun seluruh warga sekolah serta pada umumnya seluruh masyarakat agar bisa menghargai perbedaan-perbedaan.

\section{Disiplin}

Pendidikan karakter yang ditanamkan pada santri, salah satunya yaitu disiplin, dalam hal ini wakil kesiswaan dan guru BK telah membuat beberapa tata tertib disekolah terkait peraturan bagi santri agar dapat mematuhi setiap butir tata tertib yang dibuat. Apabila ada santri yang melanggar tata tertib tersebut maka diberikan pembinaan oleh guru BK, kemudian jika beberapa kali pembinaan tidak juga ada perubahan maka kembali kepada wakil kesiswaan dalam menindaklanjuti hal tersebut. Nilai pendidikan karakter yang didapatkan santri yaitu menanamkan sikap disiplin agar kiranya menjadikan diri lebih baik dalam memanajemen kedisiplin waktu, disiplin diri, disiplin tugas serta disiplin setiap proses.

\section{Kerja Keras}

Para pendidik selalu memberikan contoh sikap kerja keras kepada santri melalui beberapa aktivitas seperti belajar kejuruan, belajar al-qur'an bersama dengan metode wafa, menghafal serta muroj'ah bersama. Karena agama islam mengajarkan umatnya agar selalu bekerja keras dalam menjalankan kehidupan dimuka bumi ini. Nilai pendidikan karakter yang didapatkan santri yaitu menanamkan rasa kerja keras dalam melakukan setiap apa yang diinginkan, jika dengan kerja keras maka insya Allah apa yang kita inginkan tercapai, karena Allah menyuruh hamba-Nya untuk selalu bekerja keras dalam melakukan hal-hal kebaikan. 6. Kreatif

Untuk mencapai nilai kreatifitas ini di SMK IT Khoiru Ummah khususnya guru kejuruan, karena setiap kejuruan ada mata pelajaran produk kreatif dan kewirausaan (PKDK). Pada mata pelajaran PKDK tersebut santri diajarkan dalam berwirausaha melalui ide kreatif atau karya sendiri yang nantinya akan dipasarkan. Selain dari pada itu juga SMK IT Khoiru Ummah sekolah unggulan pencetak wirausaha, dengan pencetak wirausaha itu sekolah selalu memberikan pelatihan kreatifitas dalam pengembangan diri para santri. Nilai pendidikan karakter yang didapatkan santri yaitu menanamkan ide-ide kreatif dalam mengembangkan kehidupan yang lebih baik melalui berwirausaha ataupun membuat karyakarya yang bermanfaat bagi diri santri pribadi maupun masyarakat luas. 
7. Mandiri

Para santri SMK IT Khoiru Ummah dituntut untuk mandiri dalam melakukan apapun asalkan itu bertujuan kebaikan, dalam hal ini sesuai program sekolah bahwa ada pembuatan tanaman obat keluarga. Dimana pelaksanaan pembuatan tanaman obat keluarga ini diserahkan langsung kepada para santri secara mandiri dan nanti hasilnya akan dinilai setiap sebulan sekali. Kemudian display kelas masing-masing yang diperlombakan antar kelas dan itu juga santri dituntut untuk mandiri mendisplay kelasnya serta tugas mandiri lainnya dalam mengambil sebuah keputusan secara individu. Nilai pendidikan karakter yang didapatkan oleh santri yaitu melatih tanggungjawab, melatih keterampilan, tidak bergantung pada orang lain, percaya diri, berfikir kreatif, mempunyai pikiran kritis, mengembangkan daya mental dan jadi pemberani.

\section{Demokratis}

Dalam hal demokratis para pendidik memberikan hak kebebasan mengenai bersikap, berfikir, dan bertindak selagi demi kemajuan serta kebaikan bersama tanpa melanggar peraturan sekolah. Nilai pendidikan karakter yang didapatkan oleh santri yaitu, membiasakan diri bertidak secara demokratis dalam segala hal, membiasakan diri menyelasaikan masalah secara musyawarah, membiasakan diri mengadakan perubahan secara damai dan tidak dengan kekerasan, menuntut hak setelah melaksanakan kewajiban, menggunakan kebebasan dengan rasa tanggungjawab, mau menghormati pendapat orang lain serta membiasakan diri memberi kritik dan saran yang membangun.

9. Rasa ingin tahu

Dalam memberikan rasa ingin tahu terhadap santri, para pendidik memberikan pelayanan terbaik sesuai tugas dan kemampuan yang dimilikinya. Pemberian tersebut sudah wajib bagi pendidik dalam memberikan pelajaran atau ilmu pengetahuan kepada santri sesuai bidangnya masing-masing dengan metode pembelajaran yang berbeda-beda sesuai kebutuhan para santri, karena tidak semua santri memiliki kemampuan cepat dalam menangkap materi pembelajaran yang diberikan. Kemudian guru BK sangat berperan dan ikut andil dalam memberikan pengetahuan kepada para santri guru BK memberikan beberapa layanan seperti layanan konseling individu, layanan penempatan dan penyaluran, layanan penguasaan konten, layanan informasi, layanan orientasi, layanan bimbingan kelompok, layanan konseling kelompok. Dimana setiap layanan yang diberikan akan memberikan manfaat rasa ingin tahu dalam pengembangan diri pribadi santri. Nilai pendidikan karakter yang didapatkan oleh santri yaitu sikap atau dorongan yang kuat 
sehingga menumbuhkembangkan menjadi santri yang berpengetahuan serta intelektual yang tinggi.

10. Semangat Kebangsaan

Dalam menumbuhkan semangat kebangsaan, SMK IT Khoiru Ummah selalu membuat program peringatan hari besar nasional seperti hari pahlawan, hari pancasila, hari kartini, hari sumpah pemuda, hari guru nasioanal, hari pendidikan nasional, serta hari kemerdekaan. Semua itu bertujuan agar santri selalu mengenang jasa para pahlawan dan bisa mengambil nilai-nilai yang terkandung dalam sebuah peristiwa tersebut yang nantinya akan menjadi ilmu pengetahuan serta tumbuhnya rasa semangat kebangsaan. Nilai pendidikan karakter yang didapatkan oleh santri yaitu cara berfikir, bertindak serta wawasan yang menempatkan kepentingan bangsa dan negara diatas kepentingan pribadi maupun kelompok.

\section{Cinta Tanah Air}

Mengenai cinta tanah air, guru mata pelajaran PKN serta berkolaborasi dengan guru BK untuk membantu dan mewujudkan rasa cinta tanah air kepada para santri. Dimana guru mata pelajaran PKN memberikan materi terkait pancasila, karena didalam pancasila tersebut membahas seluruh aspek kehidupan berbangsa dan bernegara khususnya cinta terhadap tanah air. Nilai pendidikan karakter yang didapatkan oleh santri yaitu berfikir, bersikap dan berbuat dengan menunjukkan kesetiaan, kepedulian serta penghargaan yang tinggi terhadap isi sempah pemuda.

\section{Menghargai prestasi}

Menghargai prestasi sangatlah penting bagi para santri, dalam hal ini SMK IT Khoiru Ummah mempunyai program unggulan yaitu Bina Pribadi Islam (BPI), dimana BPI tersebut berkolaborasi dengan guru BK dalam membina para santri untuk meyakinkan dirinya terhadap apa yang mereka raih baik mengenai prestasi akademik maupun non akademik. Dalam meyakinkan hal tersebut murobbi dan guru BK memberikan pembinaan sesuai syariat islam apabila mendapatkan prestasi yang tinggi, santri diharapkan tidak menyombongkan diri begitupun sebaliknya jika mendapatkan prestasi yang rendah diharapkan tidak berputus asa. Karena semua yang didapatkan itu sudah takdir dari Allah SWT yang harus disyukuri. Nilai pendidikan karakter yang didapatkan oleh santri yaitu sikap dan tindakan yang mendorong dirinya menghasilkan sesuatu serta dapat mengakui hasil orang lain terkhususnya selalu mensyukuri apa yang yang telah didapatkan dan janganlan berputus asa. 


\section{Bersahabat atau Komunikatif}

Dalam menyikapi bersahabat atau komunikatif ini guru BK ambil alih mengenai hal ini, dimana guru BK memberikan layanan bimbingan kelompok. Kenapa bimbingan kelompok karena jelas tujuannya untuk mendorong pengembangan perasaan, pikiran, persepsi, wawasan dan sikap yang menunjang perwujudan tingkah laku yang lebih efektif, yaitu peningkatan kemampuan berkomunikasi baik verbal maupun non verbal para santri. Nilai pendidikan karakter yang didapatkan oleh santri yaitu melatih mereka untuk saling menhargai pendapat, persepsi, wawasan, kebersamaan, berteman bersikap sopan, tidak berbuat kasar dan tidak main hakim sendiri serta komunikasi yang baik yang nantinya diterapkan dalam kehidupan bersosial dimasyarakat.

\section{Cinta Damai}

Dalam menciptakan lingkungan disekolah yang cinta damai, para pendidik yang menjadi contoh teladan yang baik selalu membawa suasana kedamaian dan mengajarkan serta mendidik secara lemah lembut dengan penuh kasih sayang dan kehangatan kepada santri sehingga santripun terasa nyaman, senang dan damai ketika disekolah. Para pendidik pun selalu mengingatkan kepada santri setiap selesai sholat dzuhur agar dimanapun kita berada jadilah seperti madu yang selalu memberi manfaat dan cinta damai kepada orang lain. Nilai pendidikan karakter yang didapatkan oleh santri yaitu membangun rasa kebersamaan, rasa kepemilikan, bersikap anti kekerasan, peduli terhadap sesama dan rasa keakraban baik bersama teman maupun guru serta terhadap orang lain.

\section{Gemar Membaca}

Untuk menumbuhkan rasa gemar membaca para santri, di SMK IT Khoiru Ummah telah menyediakan perpustakaan yang lengkap dengan program pojok baca, dimana para santri pada waktu istirahat atau waktu luang diwajibkan satu hari membaca sebuah buku, baik buku pelajaran, cerita, novel dan lainnya yang bermanfaat untuk menambah pengetahuan bagi mereka, karena orang cerdas itu banyak membaca dan buku juga adalah jendela dunia. Nilai pendidikan karakter yang didapatkan oleh santri yaitu menanamkan nilai minat gemar membaca agar menambah ilmu pengetahuan dan melatih agar tidak bermalasan sehingga menyia-nyiakan waktu yang tidak bermanfaat.

16. Peduli Lingkungan

Dalam menciptakan santri yang peduli lingkungan, wakil kesiswaan telah membuat program sabtu bersih. Dimana setiap hari sabtu para pendidik dan santri melakukan kebersihan lingkungan sekolah maupun di tempat-tempat yang memungkinkan akan 
dibersihkan salah satunya dilingkungan masyarakat dengan bekerja sama dengan masyarakat untuk bergotong royong membersihkan disekitar pemukiman warga ataupun dilokasi yang terjadi bencana. Nilai pendidikan karakter yang didapatkan oleh santri yaitu rasa kepedulian, menjaga kebersihan sekitar, mencintai alam sebagai ciptaan Allah, rasa saling tolong-menolong, rasa kebersamaan dan menciptakan lingkungan yang bersih, indah nan elok.

\section{Peduli social}

Untuk menumbuhkan rasa peduli social bagi para santri, wakil kesiswaan berkolaborasi dengan OSIS membuat program peduli social. Dimana program itu menciptakan rasa kepedulian terhadap kejadian social yang terjadi seperti memberikan bantuan kepada para santri yang sedang membutuhkan, membantu masyarakat seperti terkena musibah, bakti social, membela sesame yang benar dan tidak membulyi. Nilai pendidikan karakter yang didapatkan oleh santri yaitu adanya sikap peduli, sikap menghargai dan sikap solidaritas terhadap teman maupun masyarakat.

18. Tanggungjawab

Untuk membentuk rasatanggungjawab para peserta, guru PKN, PAI berkolaborasi dengan guru BK dalam menumbuhkan rasa tanggungjawab ini, disini dititik fokuskan pada guru BK yang memberi layanan orientasim layanan informasi dan layanan bimbingan kelompok. Agar santri dapat bertanggungjawab atas apa yang setiap mereka perbuat baik pada diri pribadi maupun pada orang lain. Nilai pendidikan karakter yang didapatkan oleh santri yaitu agar dapat dipercaya oleh orang lain, membina hubungan yang lama, mampu menunjukkan belas kasih kepada orang lain, tidak menyalahkan orang lain dan mampu menjadi pemimpin yang dapat diandalkan oleh orang lain.

\section{Pembahasan}

Dari paparan data hasil penelitian tersebut diatas dapat diketahui bahwa pelaksanaan program pendidikan karakter di SMK IT Khoiru Ummah sudah mencakup semua nilai-nilai yang harus dikembangkan dalam pendidikan karakter di Indonesia oleh Kementerian Pendidikan Nasional yang diidentifikasi dari 4 sumber yaitu, agama, pancasila, budaya dan tujuan pendidikan nasional (Zubaedi, 2011). Dimana identifikasi keempat sumber tersebut menghasilkan 18 (delapan belas) indikator nilai-nilai pendidikan karakter yang diharapkan.

Dari konsep pendidikan karakter, menurut Ratna Megawangi (Kesuma, 2013) pendidikan karakter adalah "sebuah usaha untuk mendidik anak-anak agar dapat mengambil 
keputusan yang bijak dan mempraktikkannya dalam kehidupan sehari-hari, sehingga mereka dapat memberikan kontribusi yang positif kepada lingkungannya".

Di SMK IT Khoiru Ummah Rejang Lebong, banyak program kegiatan yang telah dilaksanakan dalam rangka untuk mewujudkan harapan dari pelaksanaan pendidikan karakter. Dimana kegiatan yang dilakukan sebagai upaya untuk menanamkan nilai-nilai luhur kepada siswa agar terbentuk kepribadian yang berkarakter, dan dikehendaki oleh masyarakat seta digunakan sebagai kekuatan dalam hidupnya.

Adapun kegiatan-kegiatan yang telah dilakukan oleh SMK IT Khoiru Ummah terkait pelaksanaan pendidikan karakter antara lain:

1. Sholat dhuha, pembacaan al-ma'surat, muroj'ah, baca A-qur'an dengan metode wafa (cara cepat baca Al-qur'an) yang semua itu dilakukan setiap pagi sebelum pembelajaran dimulai. Kemudian sholat dzuhur berjamaah dilanjutkan dengan dzikir, do'a dan setelah itu dilanjutkan pembacaan hadits secara bersama-sama.

2. Tugas individu maupun kelompok, setoran hafalan dan mengadakan sebuah kantin 'kejujuran' .

3. Bertoleransi dengan menggunakan beberapa layanan dalam konseling yaitu, layanan informasi dan bimbingan kelompok. Dalam memberikan layanan tersebut guru BK memberikan pemahaman mengenai sikap toleransi antar teman sebaya, guru dan seluruh warga SMK IT Khoiru Ummah serta masyarakat luas.

4. Wakil kesiswaan dan guru BK membuat beberapa tata tertib disekolah terkait peraturan bagi santri agar dapat mematuhi setiap butir tata tertib yang dibuat.

5. Contoh sikap kerja keras kepada santri melalui beberapa aktivitas seperti belajar kejuruan, belajar al-qur'an bersama dengan metode wafa, menghafal serta muroj'ah bersama.

6. Setiap kejuruan ada mata pelajaran produk kreatif dan kewirausahaan (PKDK). Pada mata pelajaran PKDK tersebut santri diajarkan dalam berwirausaha melalui ide kreatif atau karya sendiri yang nantinya akan dipasarkan.

7. Ada pembuatan tanaman obat keluarga. Dimana pelaksanaan pembuatan tanaman obat keluarga ini diserahkan langsung kepada para santri secara mandiri dan nanti hasilnya akan dinilai setiap sebulan sekali.

8. Dalam memenuhi rasa ingin tahu santri, para pendidik memberikan pelayanan terbaik sesuai tugas dan kemampuan yang dimilikinya. 
9. Guru mata pelajaran PKN berkolaborasi dengan guru BK untuk membantu dan mewujudkan rasa cinta tanah air kepada para santri.

10. Menghargai prestasi sangatlah penting bagi para santri, dalam hal ini SMK IT Khoiru Ummah mempunyai program unggulan yaitu Bina Pribadi Islam (BPI).

11. Dalam menciptakan sikap bersahabat atau komunikatif dalam diri santri, guru BK memberikan layanan bimbingan kelompok dengan berbagai topik tugas dan topik bebas terkait komunikasi efektif dan komunikasi antar pribadi.

12. Dalam menciptakan lingkungan disekolah yang cinta damai, para pendidik yang menjadi contoh teladan yang baik selalu membawa suasana kedamaian dan mengajarkan serta mendidik secara lemah lembut dengan penuh kasih sayang dan kehangatan kepada santri sehingga santripun terasa nyaman, senang dan damai ketika disekolah.

13. Untuk menumbuhkan rasa gemar membaca para santri, di SMK IT Khoiru Ummah telah menyediakan perpustakaan yang lengkap dengan program pojok baca, dimana para santri pada waktu istirahat atau waktu luang diwajibkan satu hari membaca sebuah buku.

14. Dalam menciptakan santri yang peduli lingkungan, wakil kesiswaan telah membuat program sabtu bersih.

15. Untuk menumbuhkan rasa peduli social bagi para santri, wakil kesiswaan berkolaborasi dengan OSIS membuat program peduli social.

Untuk membentuk rasatanggungjawab para peserta, guru PKN, PAI berkolaborasi dengan guru BK dalam menumbuhkan rasa tanggungjawab ini, disini dititik fokuskan pada guru BK yang memberi layanan orientasi, layanan informasi dan layanan bimbingan kelompok.

\section{KESIMPULAN}

Berdasarkan riset dapat disimpulkan, bahwa: 1) Pembangunan pendidikan karakter menjadi suatu keharusan, karena dunia pendidikan tidak hanya mejadikan peserta didik menjadi cerdas, akan tetapi mepunyai budi pekerti yang luhur serta sopan santun, sehingga kedepannya sebga angota masyarakat menjadi bermakna baik bagi diri sendiri maupun orang lain; dan 2) Di SMKIT Khoiru Ummah Rejang Lebong secara umum telah menanamkan pendidikan karakter kepada seluruh santrinya melalui berbagai jenis program unggulan sekolah yang dilaksanakan sesuai dengan tuntutan nilai-nilai yang ada dalam pendidikan karakter. 


\section{DAFTAR RUJUKAN}

Abror, T. (2011). Pengelolaan Pendidikan Karakter Di Sekolah. Tribakti: Jurnal Pemikiran Keislaman, 22(2), 117-130.

Sabiq, A.F. (2020). Pendidikan Karakter dalam Surat Luqman: Ayat 13-19. Retrieved 29 November, 2021 from pdfcoffee website: https://pdfcoffee.com/pendidikan-karakterdalam-surat-luqman-ayat-13-19-pdf-free.html.

Amri, S., Jauhari, A., \& Elisah, T. (2011). Implementasi pendidikan karakter dalam pembelajaran. Jakarta: PT. Prestasi Pustakaraya.

Aisyah, N., Emosda, \& Suratno. (2015). Implementasi Pendidikan Karakter Di SDIT Nurul Ilmi Kota Jambi. Jurnal Tekno-pedagogi, 5(1), 50-63.

Dalimunthe, R. A. A. (2015). Strategi dan implementasi pelaksanaan pendidikan karakter di SMP N 9 Yogyakarta. Jurnal Pendidikan Karakter, 1(1), 102-111.

Hamid, A., \& Sudira, P. (2013). Penanaman Nilai-Nilai Karakter Siswa Smk Salafiyah Prodi Tkj Kajen Margoyoso Pati Jawa Tengah. Jurnal Pendidikan Vokasi, 3(2), 139152.

Warsah, I. (2018). Pendidikan Keimanan Sebagai Basis Kecerdasan Sosial Peserta Didik: Telaah Psikologi Islami. Psikis: Jurnal Psikologi Islami, 4(1), 1-16.

Warsah, I. (2021). Pendidik Inspiratif. Yogyakarta: Deepublish.

Iswantiningtyas, V., \& Wulansari, W. (2018). Pentingnya Penilaian Pendidikan Karakter Anak Usia Dini. Proceedings of the ICECRS, 1(3), 197-204

Karim, N. (2010). Pendidikan Karakter. Shautut Tarbiyah, 16(1), 69-89.

SP, J. I. (2016). Penanaman Nilai-Nilai Karakter Melalui Implementasi Pendidikan Karakter Di Sekolah Dasar. Paper presented at Prosiding Seminar Nasional Inovasi Pendidikan, Solo: Widyasari.

Kautsar, A., \& Edi, J. (2017). Pendidikan Karakter Religius, Disiplin dan Bakat Melalui Penigkatkan Kualitas Sarana Prasarana Sekolah. JMKSP (Jurnal Manajemen, Kepemimpinan, dan Supervisi Pendidikan), 2(2), 259-277.

H Hartini . (2017). Persepsi Keluarga Muallaf tentang Pendidikan Agama Islam. Paper presented at Proceedings International Conference: On Indonesian Islam, Education and Science the Prospects and Challenges in the East and the West. Kalimantan: IAIN Palangkaraya.

Putri, D. P. (2018). Pendidikan Karakter Pada Anak Sekolah Dasar Di Era Digital. ARRIAYAH: Jurnal Pendidikan Dasar, 2(1), 37-50.

Ramdhani, M. A. (2017). Lingkungan pendidikan dalam implementasi pendidikan karakter. Jurnal Pendidikan UNIGA, 8(1), 28-37.

Retno, L. (2012). Pendidikan Karakter dalam Metode Aktif, Inovatif, dan Kreatif. Jakarta: Esensi Erlangga Group.

Salahudin, A., \& Alkrienciehie, I. (2013). Pendidikan Karakter: Pendidikan Berbasis Agama \& Budaya Bangsa. Sukoharjo: Pustaka Setia.

Setiardi, D., \& Mubarok, H. (2017). Keluarga Sebagai Sumber Pendidikan Karakter Bagi Anak. Tarbawi: Jurnal Pendidikan Islam, 14(2), 135-146.

Siswanto, Nurmal, I., \& Budin, S. (2021). Penanaman Karakter Religius Melalui Metode Pembiasaan. AR-RIAYAH: Jurnal Pendidikan Dasar, 5(1), 1-11.

Suyadi. (2013). Strategi Pembelajaran Pendidikan Karakter. Bandung: PT. Remaja Rosdakarya.

Suwito, A. (2012). Integrasi Nilai Pendidikan Karakter ke dalam Mata Pelajaran Pendidikan Kewarganegaraan di Sekolah Melalui RPP. CIVIS, 2(2), 1-21. 
Hasanah, U. (2016). Model-Model Pendidikan Karakter Di Sekolah. Al-Tadzkiyyah: Jurnal Pendidikan Islam, 7(1), 18-34.

Yanto, M. (2020). Manajemen Kepala Madrasah Ibtidaiyah Dalam Menumbuhkan Pendidikan Karakter Religius Pada Era Digital. Jurnal Konseling dan Pendidikan, $8(2), 176-183$.

Zubaedi, M. A. (2015). Desain Pendidikan Karakter. Jakarta: Prenada Media.

Zusnani, I. (2012). Manajemen Pendidikan Berbasis Karakter Bangsa. Jakarta: Tugu. 